\title{
ESTIMATION METHODS OF REFERENCE EVAPOTRANSPIRATION (ETo) FOR UBERLÂNDIA -MG
}

Doi:http://dx.doi.org/10.1590/1809-4430-Eng.Agric.v35n 1p27-38/2015

\section{ZILDA C. DE LACERDA ${ }^{1}$, JOSÉ E. P. TURCO ${ }^{2}$}

\begin{abstract}
One approach to verify the adequacy of estimation methods of reference evapotranspiration is the comparison with the Penman-Monteith method, recommended by the United Nations of Food and Agriculture Organization - FAO, as the standard method for estimating $\mathrm{ET}_{0}$. This study aimed to compare methods for estimating $\mathrm{ET}_{0}$, Makkink (MK), Hargreaves (HG) and Solar Radiation (RS), with Penman-Monteith (PM). For this purpose, we used daily data of global solar radiation, air temperature, relative humidity and wind speed for the year 2010, obtained through the automatic meteorological station, with latitude $18^{\circ} 91^{\prime} 66 " \mathrm{~S}$, longitude $48^{\circ} 25^{\prime} 05^{\prime \prime} \mathrm{W}$ and altitude of $869 \mathrm{~m}$, at the National Institute of Meteorology situated in the Campus of Federal University of Uberlandia - MG, Brazil. Analysis of results for the period were carried out in daily basis, using regression analysis and considering the linear model $\mathrm{y}=\mathrm{ax}$, where the dependent variable was the method of Penman-Monteith and the independent, the estimation of $\mathrm{ET}_{0}$ by evaluated methods. Methodology was used to check the influence of standard deviation of daily $\mathrm{ET}_{0}$ in comparison of methods. The evaluation indicated that methods of Solar Radiation and PenmanMonteith cannot be compared, yet the method of Hargreaves indicates the most efficient adjustment to estimate ETo.
\end{abstract}

KEYWORDS: penman-monteith, hargreaves, makkink, solar radiation.

\section{MÉTODOS DE ESTIMATIVA DA EVAPOTRANSPIRAÇÃO DE REFERÊNCIA (ETo), PARA UBERLÂNDIA - MG}

RESUMO: Uma forma de verificar a adequação de métodos de estimativa da evapotranspiração de referência (ETo) é a comparação com o método de Penman-Monteith, recomendado pela Organização das Nações Unidas para Alimentação e Agricultura - FAO, como método-padrão para estimativa da ETo. Este estudo teve por objetivo comparar os métodos de estimativa da ETo, Makkink (MK), Hargreaves (HG) e Radiação Solar (RS), com o método de Penman-Monteith (PM). Para tanto, utilizaram-se dados diários de radiação solar global, velocidade do vento, temperatura e umidade relativa do ar para o ano de 2010, obtidos na estação meteorológica automática, com latitude de $18^{\circ} 91^{\prime} 66^{\prime}$ 'S, longitude de $48^{\circ} 25^{\prime} 05^{\prime}$ 'W e altitude de $869 \mathrm{~m}$, do Instituto Nacional de Meteorologia, instalado no Câmpus da Universidade Federal de Uberlândia - MG. As análises dos resultados foram feitas para o período diário, utilizando-se da análise de regressão linear $\mathrm{y}=\mathrm{a} \mathrm{x}$, na qual a variável dependente foi o método de Penman-Monteith, e a independente, as estimativas da ETo pelos métodos avaliados. Utilizou-se da metodologia que verifica a influência do desvio-padrão diário da ETo na comparação dos métodos estudados. Os métodos de Radiação Solar e PenmanMonteith não podem ser comparados, já o método de Hargreaves indica ajuste mais eficiente para a estimativa da ETo.

PALAVRAS-CHAVE: penman-monteith, hargreaves, makkink, radiação solar.

\section{INTRODUCTION}

Agricultural activities require great amounts of water and, facing the matter of reasonable use of this natural resource; efforts have been employed in the development of practices that enable its

\footnotetext{
${ }^{1}$ Zilda Corrêa de Lacerda, Enga Agrônoma, Prof ${ }^{a}$. Doutora, Instituto Federal do Triângulo Mineiro - IFTM, Campus Uberlândia- Uberlândia-MG, Fone: (34) 32338859, zilda@iftm.edu.br.

${ }^{2}$ José Eduardo Pitelli Turco, Eng ${ }^{\circ}$ Eletricista, Prof. Adjunto, Departamento de Engenharia Rural, UNESP - Jaboticabal - SP, Fone: (16) 32097278, jepturco@fcav.unesp.br. 
efficient use. In this manner, one of the essential requirements to estimate the quantity of water necessary for agricultural production is the effective understanding of relations between climate conditions and evapotranspiration. The evapotranspiration (ET) is defined as a simultaneous occurrence of two different processes, water evaporation directly from soil surface or from surfaces of free water and transpiration through plant stomas (ALLEN et al., 2006).

The knowledge about evapotranspiration is essential in activities related to river basin management, refilling of aquifers (LIANG et al., 2010), meteorological and hydrological modeling and, above all, in the dynamics of soil humidity and water management of irrigated agriculture (BEZERRA et al., 2008). The quantification of ET is fundamental to identify time variations about irrigation necessity, improve allocation of water resources and evaluate changes in water balance management (ORTEGA-FARIAS et al., 2009).

JENSEN (1970) introduced the concept of reference evapotranspiration (ETo). The bulletin of Irrigation and Drainage 56 of the Food and Agriculture Organization - FAO (ALLEN et al., 1998) defines ETo as evapotranspiration rate of a reference surface, covered by a hypothetical crop, with height of $0.12 \mathrm{~m}$, surface aerodynamic resistance of $70 \mathrm{~s} \mathrm{~m}^{-1}$ and albedo of 0.23 , with no restrictions of humidity, active growth and completely covering soil surface (ALLEN et al., 1998). This concept was originally introduced to investigate atmosphere evaporative demand, independently of the type of culture, phenology and cultivation treatments (ALENCAR et al., 2011).

ET can be measured directly by specific equipments, or determined by micrometeorological methods, in carefully planned experiments, of high cost and long term (KUMAR et al., 2008). As an alternative to direct measurement, several researchers developed estimation methods by means of hydro meteorological models (MAEDA et al., 2011) and mathematical models (LANDERAS et al., 2008). These estimation methods involve fewer variables and are frequently used to estimate $\mathrm{ET}_{0}$ in different situations and places.

The methods recommended by the United Nations of Food and Agriculture Organization (FAO) in 1977 were submitted to a revision accomplished by specialists in evapotranspiration, who concluded that the method FAO Penman-Monteith presented better results for ETo estimation with climate variables (ALLEN et al., 1998), being recommended as the standard estimation method of ETo (ALLEN et al., 2006).

Studies comparing estimation methods of ETo in relation to method of Penman-Monteith parameterized by FAO are performed for different regions in Brazil and worldwide, as a way to evaluate efficiency of indirect methods (VESCOVE \& TURCO, 2005; GAVILÁN et al., 2007; REIS et al., 2007; PEREIRA et al., 2009; TAGLIAFERRE et al., 2010; FRANÇA NETO et al., 2011; CAVALCANTE JÚNIOR et al., 2011; ALENCAR et al., 2011; PILAU et al., 2012; BORGES JÚNIOR et al., 2012). The results of conducted research varied extremely, since each region present peculiar climate characteristics and the estimation methods of ETo exhibits problems of precision and accuracy, mainly because of the non-adjustment of model coefficients and sensors accuracy (BARROS et al., 2009). These empirical methods are based on observations and statistical analysis, generally adequate for a climate condition or specific region (FOOLADMAND \& AHMADI, 2009).

In order to contribute for research of this nature, this study was conducted aiming to evaluate the efficiency of estimation methods of reference evapotranspiration denominated of, Makkink (MAKKINK, 1957), Hargreaves (HARGREAVES, 1976) and Solar Radiation (DOORENBOS \& PRUITT, 1977), comparing them to the method Penman-Monteith FAO (ALLEN et al., 1998), for the climate conditions of Uberlandia - MG.

\section{MATERIAL AND METHODS}

Data was obtained from automatic meteorological station (model MAWS301, Vaisala, Helsinki, Finland) of the Fifth Meteorological District of National Institute of Meteorology INMET, located at the Campus of Federal University of Uberlândia - MG, at latitude 18 91' 66' S, 
longitude $48^{\circ} 25^{\prime} 05^{\prime}$ ' W, altitude of $869 \mathrm{~m}$. According to Köeppen classification, the climate in the region is $\mathrm{Cwa}$, mesothermal with hot and rainy summer and cold and dry winter. Accessed data are time reports, referent to the period from January 1 to December 31 of 2010.

The parameters were temperature, air relative humidity, wind speed and global solar radiation. Air temperature was measured with the aid of a thermometer (model HMP45A, Vaisala, Helsinki, Finland), with accuracy of $\pm 0.2^{\circ} \mathrm{C}$ and the air relative humidity measured with a hygrometer (model HMP45D, Vaisala, Helsinki, Finland), accuracy of $\pm 1 \%$, using termohigrometer Vaisala brand. Wind speed was obtained through an anemometer installed at $10 \mathrm{~m}$ of soil surface (model WAA151, Vaisala, Helsinki, Finland), with operating limits between 0.4 to $75 \mathrm{~m} \mathrm{~s}^{-1}$ and accuracy of $\pm 0.17 \mathrm{~m} \mathrm{~s}^{-}$ 1. Global Solar Radiation was accessed with the support of a pyrometer (model CMP6, Vaisala, Helsinki, Finland) accuracy $\pm 20 \mathrm{~W} \mathrm{~m}^{-2}$ and constant calibration of $12.8010^{-6} \mathrm{~V} \mathrm{~W}^{-1} \mathrm{~m}^{-2}$.

ETo was estimated in daily average scale for the year of 2010, by the methods of MAKKINK (1957), HARGREAVES (1976), Solar Radiation (DOORENBOS \& PRUITT, 1977) and PenmanMonteith FAO56 (ALLEN et al., 1998), considering the latter as a standard for comparison of the other methods.

Analysis of results was carried out for daytime, employing regression analysis and considering the linear model forced to pass in the origin, which means:

$$
y=\mathrm{ax}
$$

where,

$\mathrm{y}-$ Eto in $\mathrm{mm} \mathrm{d}^{-1}$, by Penman-Monteith method;

a - angular coefficient,

$\mathrm{x}-$ Eto in $\mathrm{mm} \mathrm{d}^{-1}$, by other methods.

The dependent variable was ETo estimated by Penman-Monteith (PM) and the independent variable was the estimations of ETo by the three studied methods. The adjustments of linear regression models for estimation method of ETo, by means of t test of Student, at $1 \%$ and $5 \%$ of probability.

The standard error of estimation (SE) between ETo estimates of evaluated methods and ETo of method PM was also examined, according to [eq. (2)]:

$$
\mathrm{SEE}=\left[\sum_{i=1}^{n}\left(Y_{i}-\hat{Y_{i}}\right)^{2} / n-1\right]^{0.5}
$$

where,

$$
\begin{aligned}
& Y_{i} \text { - ETo average by PM method; } \\
& \hat{Y}_{i} \text { - estimation of ETo by other studied methods, and } \\
& \mathrm{n} \text { - total number of observations. }
\end{aligned}
$$

The determination of standard deviation (error) technique was applied in estimation methods of reference evapotranspiration (TURCO et al., 1994; TURCO et al., 2008), in the following estimation methods of ETo: MAKKINK (1957), HARGREAVES (1976), Solar Radiation (DOORENBOS \& PRUITT, 1977) and Penman-Monteith (ALLEN et al., 1998). For this, a mathematical treatment in the original equation of these methods described by TURCO et al. (2008) was conducted. 
In order to evaluate the results, considering standard deviation (error) of ETo, methodologies of VUOLO (1996) were performed, the transfer of error from the independent variable to the dependent variable, the least squares method and the quality examination of an adjustment.

A quality evaluation criterion of adjustment is essentially a method to determine if the adjusted curve was adequate in relation to experimental points. The used criterion for quality evaluation of adjustment was the reduced $\mathrm{X}^{2}$ test, in which the quantity of reduced $\mathrm{X}^{2}$ is defined as:

$$
x_{\text {red }}^{2}=\frac{x^{2}}{v}
$$

where,

$\mathrm{X}^{2}-$ is the squares summation of distances between experimental points and adjusted curve, and

$v-$ is the number of degrees of freedom of the adjustment.

As $\mathrm{n}$ is the number of experimental points and $\mathrm{p}$ the number of adjusted parameters $v=(\mathrm{n}-\mathrm{p})$.

After obtaining $X_{\text {red }}^{2}$, quality investigation of adjustment was conducted by means of the methodology of VUOLO (1996) that relates $v$ with $X_{r e d}^{2}$ and permit to obtain, for each $v$, a confidence interval $\mathrm{P}=98 \%$, for values of $X_{\text {red }}^{2}$. In the methodology of VUOLO (1996), values of $v$ reach 160 , therefore, in the present study, $v 246$, this corresponds to 248 days of the year used in the study and the two adjusted parameters.

In order to determine $\chi_{\text {red }}^{2}(1 \%$ and $99 \%)$, the Excel software was adopted, from statistical function and followed by Inv. Qui: i) for $v=246$ at $1 \%$ of probability $X^{2}=197.35$ is obtained; therefore $X_{\text {red }}^{2}=\frac{X^{2}}{v}=0.802$ and $\quad$ ii) for $v=246$ and $99 \% \mathrm{X}^{2}=352.1$ is obtained; thus $X_{\text {red }}^{2}=\frac{X^{2}}{v}=1.431$. Along these lines, it is safe to affirm with $98 \%$ of confidence that: $0.802<$ $\chi_{\text {red }}^{2}<1.431$

From the daily average achieved by the studied methods, a linear equation that more competently adjusted to ETo estimated by parameterized method of FAO Penman-Monteith (PMFAO) was found.

Through achieved standard deviations, methodology of VUOLO (1996) was applied, for the evaluation of estimation methods of ETo in relation to the standard method PM.

\section{RESULTS AND DISCUSSION}

Initially, the linear regression analysis $(y=a x+b)$ of ETo determined by investigated methods in comparison to method PM, resulted in non significant linear coefficient (b), in accordance with t test of Student, at $1 \%$. The regression was re estimated, forced to pass through origin $(\mathrm{y}=\mathrm{a} x \mathrm{x})$, obtaining angular coefficients of the relation between ETo estimated by evaluated methods and the method of PM-FAO. 
TABLE 1. Results of regression analysis, linear model without intercept.

\begin{tabular}{|c|c|c|c|c|c|}
\hline Method & $\begin{array}{c}\text { Average ETo } \\
\left(\mathrm{mm} \mathrm{d}^{-1}\right)\end{array}$ & A & $r^{2}$ & $\mathrm{R}$ & SEE \\
\hline $\mathrm{PM}$ & 5.6 & - & & 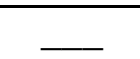 & 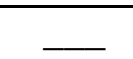 \\
\hline $\mathrm{HG}$ & 5.1 & 1.1131 & 0.7037 & 0.8389 & 0.5824 \\
\hline MK & 4.1 & 1.3894 & 0.7127 & 0.8442 & 0.5950 \\
\hline $\mathrm{RS}$ & 6.2 & 0.9104 & 0.6280 & 0.7925 & 0.6538 \\
\hline
\end{tabular}

$\mathrm{a}$ - an gular coefficient, $\mathrm{r}^{2}$-coefficient of determination, $\mathrm{r}$-coefficient of correlation, SEE- standard error of estimation.

The regression analysis results using linear model without intercept are displayed on Table 1, for the year of 2010 in Uberlândia - MG. It was possible to verify that methods of Hargreaves (HG) and Makkink (MK) underestimated daily average values of ETo, while the Solar Method (RS) overestimated.

The methods RS and HG presented values of angular coefficients in the adjustment equation of regression analysis, closer to the unit, which indicated accordance between the values estimated by these methods and the estimated by standard method PM. Greater values of $r^{2}$ were observed in method MK and HG, the two methods exhibited similar precisions when compared to method PM, with precisions of $71.3 \%$ and $70.4 \%$ respectively, which indicated that a considerable part of total variation of ETo values is explained by these methods. Similar results were found by OLIVEIRA et al. (2008) when comparing daily values of ETo by method HG and by lysimeter of hydraulic weighting, achieved value $r^{2}=0.71$ in Vitória de Santo Antão - PE. Nevertheless, the adoption of coefficient of determination $r^{2}$ as the only criterion of quality definition of methods is not adequate, since this index do not establish the type and magnitude of differences between estimated value by standard method and value predicted by estimation methods (BARROS et al., 2009). Thereby, the analysis of coefficient of correlation and standard error of estimation are auxiliaries in result interpretation.

The coefficient of correlation ( $r$ ) and the standard error of estimation (SEE) derived from comparison between estimated values of ETo by methods of HG, MK and RS with method PM showed that HG and MK with $\mathrm{r}$, respectively, of 0.8389 and 0.8442 , have positive correlation with method of PM, since variation amplitude of correlation is defined as $-1 \leq \mathrm{r} \leq 1$, and so the closer to the unit, the more effective is the correlation. The coefficient of correlation do not indicate any cause-effect relation between variables and that, only ETo estimated by standard-method PM tend to increase as ETo obtained by studied methods increase. Regarding SEE, method HG presented the smallest error, $0.58 \mathrm{~mm} \mathrm{~d}^{-1}$, this indicates lowest deviation and best adjustment in relation to standard-method PM. Similar results were achieved in the basin of Jacupiranga river - SP, by BORGES \& MENDIONDO (2007), in a study of comparison of estimation methods of ETo with standard-method PM, in which method HG presented the smallest standard-error of estimation.

The adjustment of linear model without intercept for daily average values of ETo estimated by methods of $\mathrm{HG}, \mathrm{MK}$ and RS, compared to $\mathrm{PM}$ and the respective adjustment equations and coefficients of determination are displayed on Figures 1, 2, and 3 respectively.

The regression line came close to line $\mathrm{y}=\mathrm{x}(1: 1)$ and method HG underestimated ETo in $11 \%$ in comparison to standard PM. The pairs of points are close to the regression line, showing that the studied method presents little dispersion in relation to method PM. The result of analysis of regression indicated efficient adjustment for method HG in the estimation of ETo in comparison to method PM. 


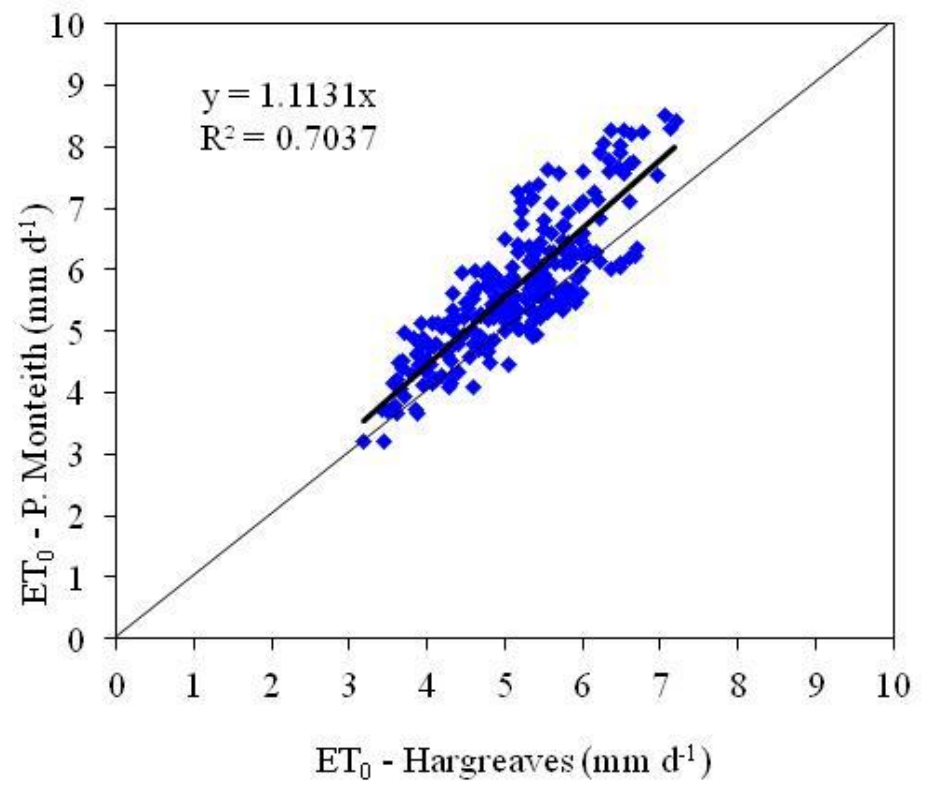

FIGURE 1. Daily average values of $\mathrm{ET}_{0}$ obtained with the method HG, in the year 2010, in relation to the method PM, for Uberlandia-MG.

Similar tendency was found by SENTELHAS et al. (2010), for 12 localities in the South of Ontario, Canada, studying methods that apply, basically, models based on air temperature, like Hargreaves, Thornthwaite and Priestley-Taylor, and observed that the first two presented greater estimations of ETo. MAEDA et al. (2011) also evaluated efficiency of estimation methods of ETo and detected that method of Hargreaves was the most appropriate for climate conditions in South Kenya, in Africa. BORGES \& MENDIONDO (2007) verified the precision of several methods, among them, Hargreaves, for the Jacupiranga river basin - SP, and indicated that method Hargreaves can be applied in its original form as well as in the modified.

In Figure 2, the littlest proximity from ETo estimated by method of Makkink in comparison to standard PM was noted and regression line is more distant from line 1:1, underestimating ETo in $38 \%$ in comparison to PM. The adjustment of estimation of ETo for methods MK in comparison to $\mathrm{PM}$ is less efficient than $\mathrm{HG}$ and RS.

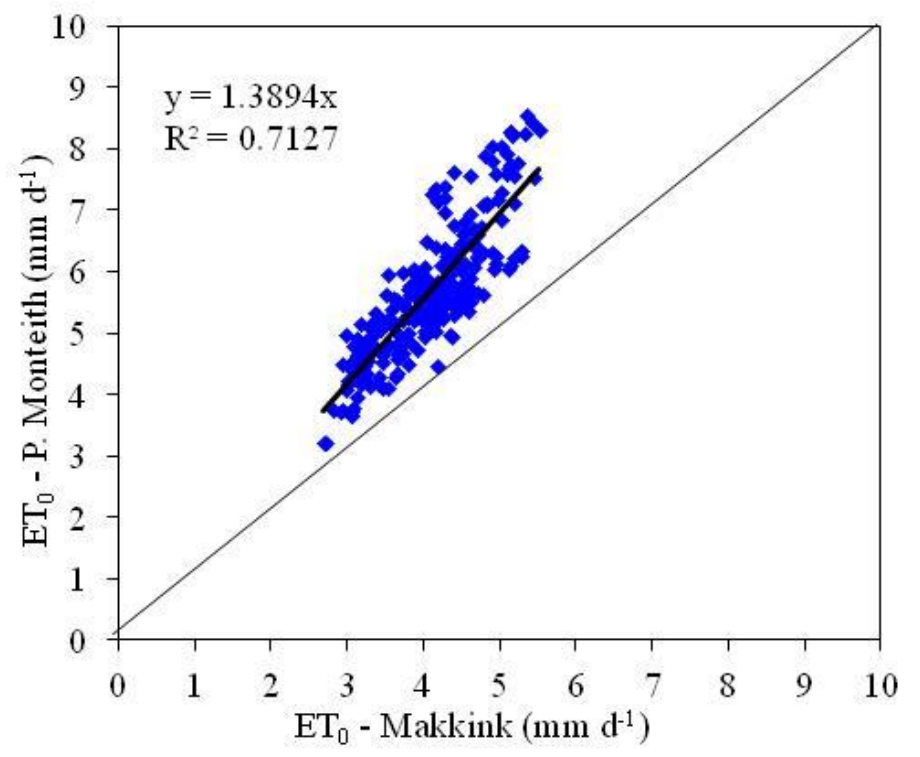

FIGURE 2. Daily average values of $\mathrm{ET}_{0}$ obtained by the method MK, in the year 2010, in relation to the method PM, for Uberlandia-MG. 
Similar results found by PILAU et al. (2012), in Frederico Westphalen and Palmeira das Missões in Rio Grande do Sul, where the method MK underestimated ETo in relation to PM used as standard in most of the months of the year. For the region of Araraquara - SP, VESCOVE \& TURCO (2005), comparing estimation methods of ETo, observed that method Makkink underestimated ETo in relation to PM during winter-spring, more substantially than in the period summer-autumn. In climate conditions of semi-arid Northeast, CAVALCANTE JÚNIOR et al. (2011), when evaluating estimation methods of ETo in relation to PM, observed that method Makkink underestimated ETo in humid and dry months, with a more severe underestimation in dry season.

In estimation of ETo by method of RS (Figure 3), it is observed that regression line is close to line $\mathrm{y}=\mathrm{x}$ and the method overestimated ETo in $9 \%$ in comparison to PM, suggesting precision of $62.8 \%$ in relation to PM and indicating greater dispersion of pairs of points, which means that method RS in comparison to method PM is inefficient.

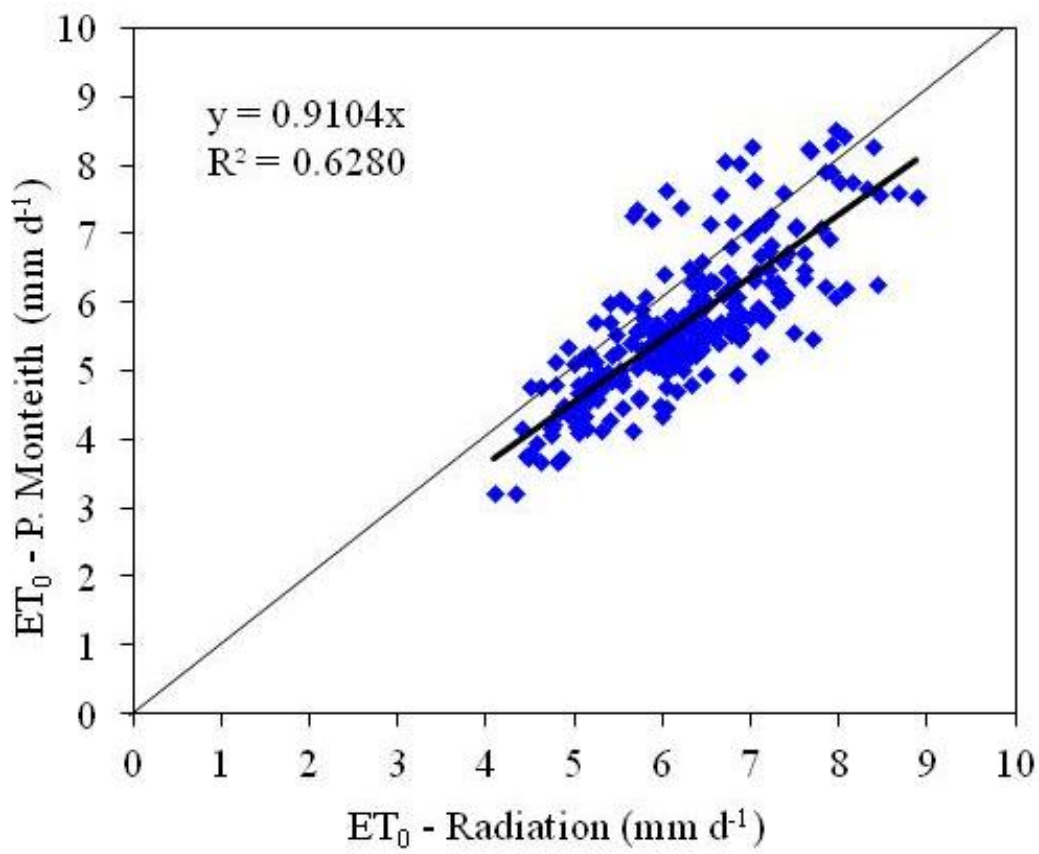

FIGURE 3. Daily average values of $\mathrm{ET}_{0}$, obtained by the Solar Radiation, in the year 2010, in relation to the method PM, for Uberlandia-MG.

Similar tendency was accessed by ALENCAR et al., (2011) for three localities of North Minas Gerais, in which the estimation of ETo by method RS overestimated ETo obtained by method PM. In Frederico Westphalen and Palmeira das Missões in Rio Grande do Sul, PILAU et al., (2012) observed that method RS overestimated ETo in relation to method PM during most of the year. In the evaluation of seven daily estimation methods of ETo for a semi-arid region in Spain, province of Albacete, LÓPEZ-URREA et al., (2006) observed that method RS overestimated ETo obtained by method of PM in 5\% when local conditions were of aridity. For the region of Araraquara - SP, VESCOVE \& TURCO (2005), comparing estimation methods of ETo, observed that method, RS overestimated ETo for the period summer-autumn more substantially than for winter-spring.

The evaluation results of estimation methods of ETo in comparison to method of PM, using analysis of regression with linear model without intercept, exhibited an adjustment that is more efficient for the method HG, followed by methods of MK and RS. The analysis of regression methodology does not consider errors of estimation of ETo due to combination of errors of variables that nurture the equations.

Considering the error associated to ETo according to application of measurement instruments, a technique of error determination was used (TURCO et al., 1994; TURCO et al., 2008). With the application of this technique, daily standard deviation (error) associated to estimation of ETo by PM was determined, in the period from January to December of 2010. In the same way, daily standard 
deviations ( $\pm \Delta \mathrm{ET}_{0} \mathrm{MK}, \pm \Delta \mathrm{ET}_{0} \mathrm{HG}, \pm \Delta \mathrm{ET}_{0} \mathrm{RS}$ ) associated to estimations of ETo by methods MK, HG and RS were achieved.

In Figures 4, 5 and 6, the lines $y=$ ax adjusted to experimental points are displayed, obtained daily by studied methods, in relation to method PM and respective uncertainties.

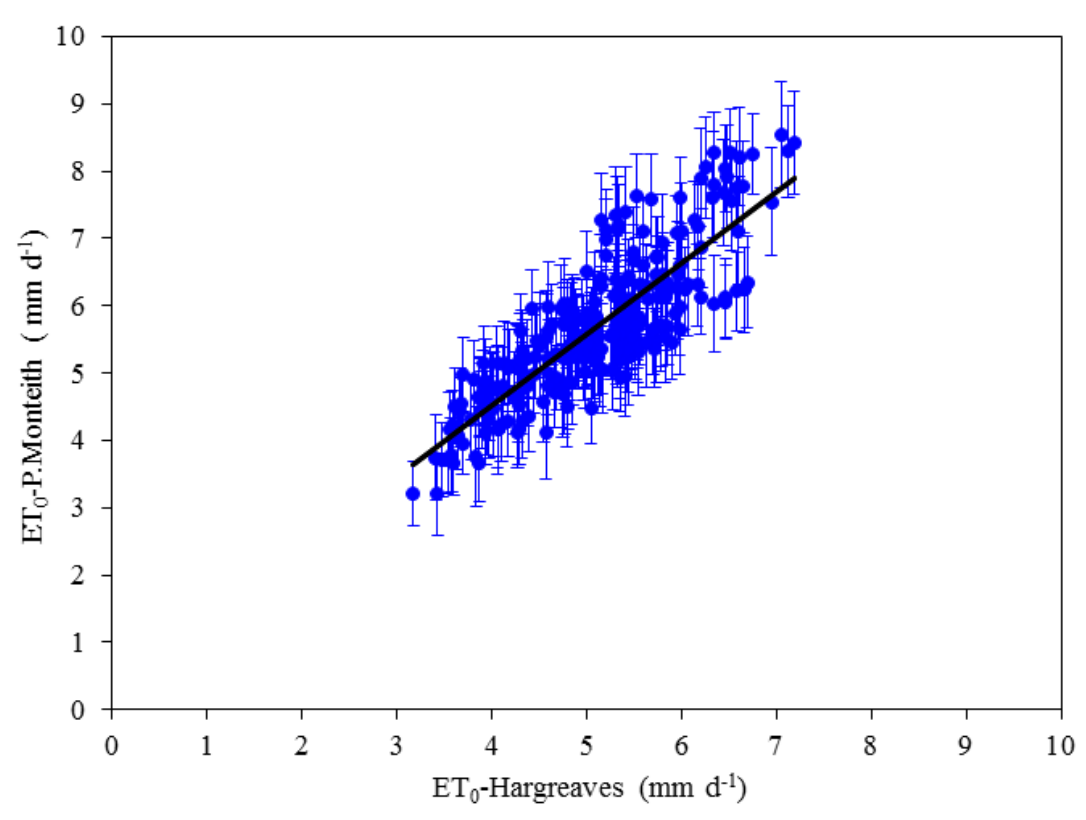

FIGURE 4. Line $y=a x$ adjusted to experimental points and respective uncertainties.

The correlation between daily values of ETo obtained by method of HG in relation to method of PM, $v=246$ and $\chi_{\text {red }}^{2}=0.901$ (Figure 4), indicates that the value of $\chi_{\text {red }}^{2}$ was found in the range of acceptable values for $\chi_{\text {red }}^{2}$ and the adjustment can be considered efficient. Evidences were statistically observed at $98 \%$ of confidence, in which method PM and HG are not distinct and therefore can be compared.

The correlation between daily values of ETo obtained by method MK in relation to PM, in adjustment of line from Figure 5,v $=246$ and $\chi_{\text {red }}^{2}=1.038$ (Figure 5), in which the value of $\chi_{\text {red }}^{2}$ was in the range of acceptable values for $\chi_{\text {red }}^{2}$ and the adjustment can be considered efficient. Again, evidences were found at $98 \%$ of confidence, in which method PM and HG are not distinct and therefore can be compared. 


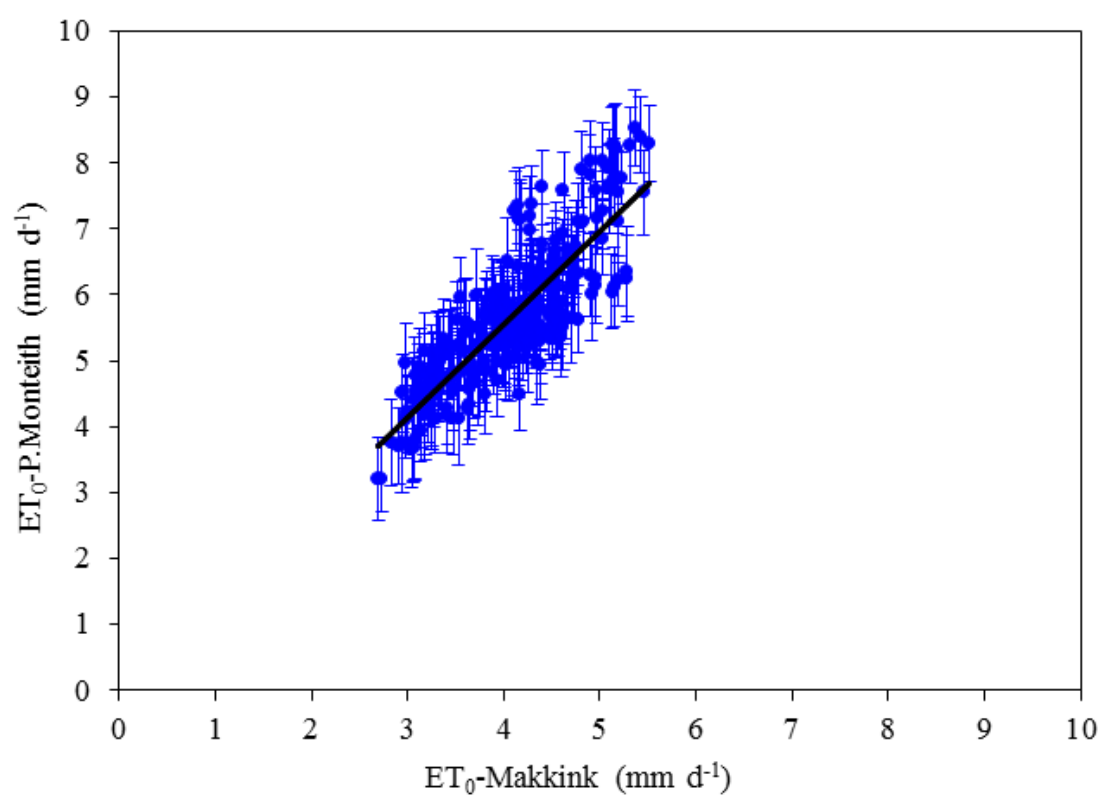

FIGURE 5. Line $y=a x$ adjusted to experimental points and respective uncertainties.

In the adjustment of line from Figure 6, the correlation between daily values of ETo obtained by method of Solar Radiation in relation to Penman-Monteith, $v=246$ and $\chi_{\text {red }}^{2}=0.161$. The value of $\chi_{\text {red }}^{2}$ was outside the range of acceptable values for $\chi_{\text {red }}^{2}$ which indicated that the adjustment is inefficient. Statistically, evidences were found, with $98 \%$ of confidence, in which method PM and RS are distinct and therefore cannot be compared.

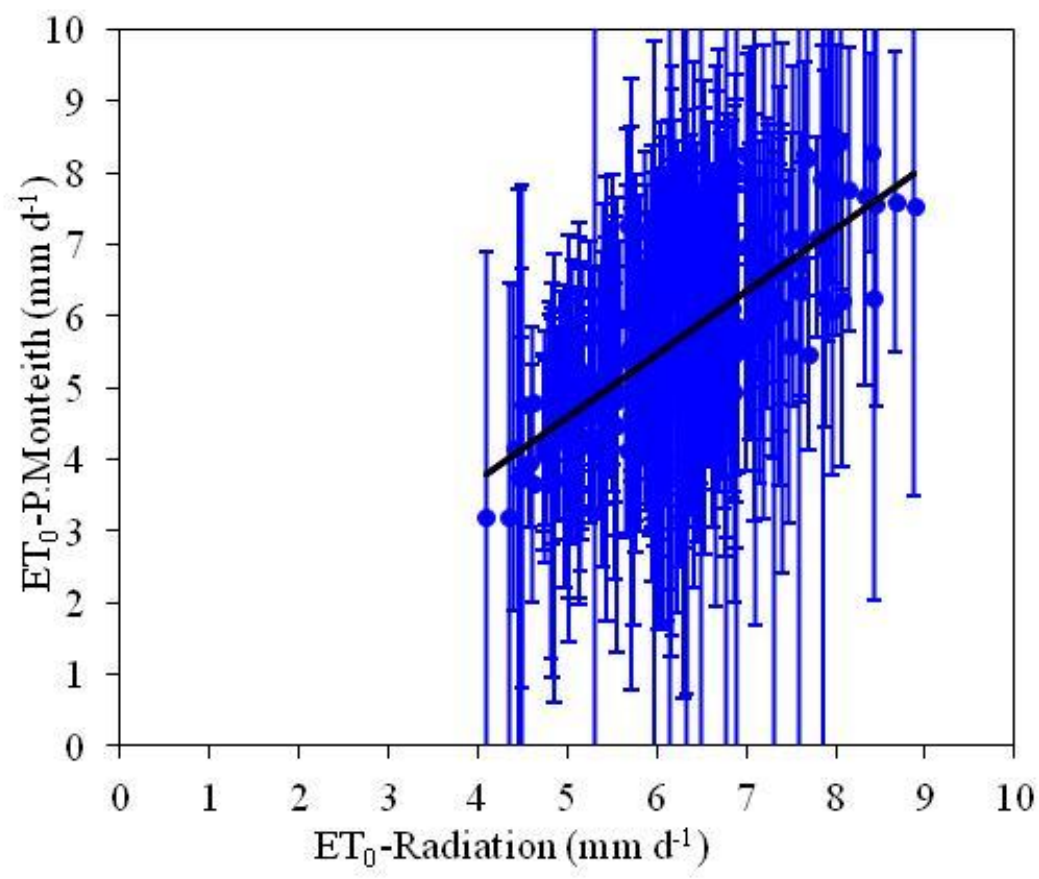

FIGURE 6. Line $y=a x$ adjusted to experimental points and respective uncertainties.

TURCO et al. (2008) found similar results in the evaluation of estimation methods of $\mathrm{ET}_{0}$ for Jaboticabal - SP, considering the errors of ETo due to use of measurement instruments. The authors cite that the best adjustment for estimation of ETo was obtained by method of Hargreaves in comparison to method PM. The Solar Radiation method is distinct from Penman-Monteith and cannot be compared, as, applying the methodology of data analysis and considering the errors of 
ETo, a linear relation is not established between this method and method PM, and therefore, they cannot be compared.

\section{CONCLUSIONS}

Regarding the studied location, the method of Hargreaves suggests best adjustments in the estimation of ETo, followed by Makkink and Solar Radiation, in comparison to standard-method Penman-Monteith.

The Solar Radiation method and the standard Penman-Monteith cannot be compared due to the influence of daily standard deviation of ETo.

\section{ACKNOWLEDMENTS}

To the Fifth Meteorological District of National Institute of Meteorology and the Climatology Laboratory of the Geography Institute of Federal University of Uberlândia, for providing meteorological data.

\section{REFERENCES}

ALENCAR, L.P.; SEDIYAMA, G.C.; WANDERLEY, H.S.; ALMEIDA, T.S.; DELGADO, R.C. Avaliação de métodos de estimativa da evapotranspiração de referência para três localidades no norte de Minas Gerais. Engenharia na Agricultura, Viçosa, MG, v.19 n.5, p.437-449, 2011.

ALLEN, R.G.; PEREIRA, L.S.; RAES, D.; SMITH, M. Crop evapotranspiration: guidelines for computing crop water requirements. Rome: FAO, 1998. 300 p (Irrigation and Drainage Paper, 56).

ALLEN, R.G.; PEREIRA, L.S.; RAES, D.; SMITH, M. Evapotraspiration del cultivo: guias para la determinación de los requerimientos de água de los cultivos. Roma: FAO, 2006. 298 p. (Estúdio Riego e Drenaje, Paper 56).

BARROS, V.R.; SOUZA, A.P.; FONSECA, D.C.; SILVA, L.B.D. Avaliação da evapotranspiração de referência na Região de Seropédica, Rio de Janeiro, utilizando lisímetro de pesagem e modelos matemáticos. Revista Brasileira de Ciências Agrárias, Recife, v.4, n.2, p.198-203, 2009.

BEZERRA, B.G.; SILVA, B.B.; FERREIRA, N.J. Estimativa da evapotranspiração real diária utilizando-se imagens digitais TM- Landsat 5. Revista Brasileira de Meteorologia, Rio de Janeiro, v.23, n.3, p.305-317, 2008.

BORGES, A.C.; MENDIONDO, E.M. Comparação entre equações empíricas para estimativa da evapotranspiração de referência na Bacia do Rio Jacupiranga. Revista Brasileira de Engenharia Agrícola e Ambiental, Campina Grande, v.11, n.3, p.293-300, 2007.

BORGES JÚNIOR, J.C.F.; ANJOS, R,J.; SILVA, T.J.A.; LIMA, J.R.S.; ANDRADE, C.L.T. Métodos de estimativa da evapotranspiração de referência diária para a microrregião de Garanhuns, PE. Revista Brasileira de Engenharia Agrícola e Ambiental, Campina Grande, v.16, n.4, p.380-390, 2012.

CAVALCANTE JÚNIOR, E.G.; OLIVEIRA, A.D.; ALMEIDA, B.M.; ESPÍNOLA SOBRINHO, J. Métodos de estimativa da evapotranspiração de referência para condições do Semiárido Nordestino. Semina: Ciências Agrícolas, Londrina, v.32, supl. 1, p.1699-1708, 2011.

DOORENBOS, J.; PRUITT, W.O. Crop water requirements. Rome: FAO, 1977. 179 p. (Irrigation and Drainage, Paper 24).

FOOLADMAND, H.R.; AHMADI, S.H. Monthly spatial calibration of Blaney-Criddle equation for calculating monthly $\mathrm{ET}_{0}$ in south of Iran. Irrigation and Drainage, slough, v.58, n.2, p.234-245, 2009.

FRANÇA NETO, A.C.; MANTOVANI, E.C.; VICENTE, M.R.; VIEIRA, G.H.S.; SEDIYAMA, G.C.; LEAL, B.G. Comparação entre métodos simplificados de estimativa da evapotranspiração de 
referência ( $\mathrm{ET}_{0}$ ) para regiões produtoras de café brasileiras. Coffee Science, Lavras, v.6, n.2, p.159$171,2011$.

GAVILÁN, P.; BERENGENA, J.; ALLEN, R.G. Measuring versus estimating net radiation and soil heat flux: impact on Penman-Monteith reference ET estimates in semiarid regions. Agriculture Water Management, Amsterdam, v.89, n.3, p.275-286, 2007.

HARGREAVES, G.H. Climate and irrigation requirements for Brazil. Logan: Utah State University, 1976. 44 p.

JENSEN, M. C. Irrigation system design capacity functions for Washington. Washington: 1970 Agricultural Experiment Station, 1970.

KUMAR, M.; BANDYOPADHYAY, A.; RAGHUWANSHI, N. S.; SINGH, R. Comparative study of conventional and artificial neural network-based estimation models. Irrigation Science, Sidney, v.26, n.6, p.531-545, 2008.

LANDERAS, G.; ORTIZ-BARRETO, A.; LÓPEZ, J.J. Comparison of artificial neural network models and empirical and semi-empirical equations for daily reference evapotranspiration estimation in the Basque Country (Northem Spain). Agricultural Water Management, Amsterdam, n.95, p.553-565, 2008.

LIANG, L.; LI, L.; LIU, Q. Temporal variation of reference evapotranspiration during 1961-2005 in the Taoer River basin of Northeast China. Agricultural and Forest Meteorology, Wageningen, v.150, n.2, p.298-306, 2010.

LÓPEZ-URREA, R.; MARTIN, S.O.F.; FABEIRO, C.; MORATALIA, A. Testing evapotranspiration equations using lysimeter observations in a Semiarid Climate. Agricultural Water Management, Amsterdam, v.85, n.1, p.15-26, 2006.

MAEDA, E.E.; WIBERG, D.A.; PELLIKKA, P.K.E. Estimating reference evapotranspiration using remote sensing and empirical models in a region with limited ground data availability in Kenya. Applied Geography, Amsterdam, v.31, n.1, p.251-258, 2011.

MAKKINK, G.H. Ekzameno de la formula de Penman. Netherlands Journal Agricultural Science, Wageningen, v.5, p.290-305, 1957.

OLIVEIRA, L.M.M.; MONTENEGRO, S.M.G.L.; AZEVEDO, J.R.G.; SANTOS, F. Evapotranspiração de referência na bacia experimental do riacho Gameleira - PE, utilizando lisímetro e métodos indiretos. Revista Brasileira de Ciências Agrárias, Recife, v.3, n.1, p.58-67, 2008.

ORTEGA-FARIAS, S.; IRMAK, S.; CUENGA, R.H. Special issue on evapotranspiration measurement and modeling. Irrigation Science, Sidney, v. 28, n.1, p. 1-13, 2009.

PEREIRA, D.R.; YANAGI, S.N.M.; MELLO, C.R.; SILVA, A.M.; SILVA, L.A. Desempenho de métodos de estimativa da evapotranspiração de referência para a região da Serra da Mantiqueira MG. Ciência Rural, Santa Maria, v.39, n.9, p.2488-2493, 2009.

PILAU, F.G.; BATTISTI, R.; SOMAVILLA, L.; RIGHI, E.Z. Desempenho de métodos de estimativa da evapotranspiração de referência nas localidades de Frederico Westphalen e Palmeira das Missões - RS. Ciência Rural, Santa Maria, v.42, n.2, p.283-290, 2012.

REIS, E.F.; BRAGANÇA, R.; GARCIA, G.O.; PEZZOPANE, J.E.M.; TAGLIAFERRE, C. Estudo comparativo da estimativa da evapotranspiração de referência para três localidades do estado do Espírito Santo no período seco. Idesia, Chile, v.25, n.3, p.75-84, 2007.

SENTELHAS, P.C.; GILlESPIE, T.J.; SANTOS, E.A. Evaluation of Penman-Monteith and alternative methods for estimating reference evapotranspiration with missing data in Southern Ontário, Canada. Agricultural Water Management, Amsterdam, v.97, n.5, p.635-644, 2010. 
TAGLIAFERRE, C.; SILVA, R.; ROCHA, F.; SANTOS, L. Estudo Comparativo de diferentes metodologias para determinação da evapotranspiração de referência em Eunápolis- BA. Revista Caatinga, Mossoró, v.23, n.1, p.103-111, 2010.

TURCO, J.E.P.; PINOTTI, J.R.; PAVANI, L.C.; FERNANDES, E.J. Técnica para determinação de erros em métodos de estimativa da evapotranspiração de referência. Engenharia Agrícola, Joboticabal, v.14, p.31-37, 1994.

TURCO, J.E.P.; PERECIN, D.; PINTO JÚNIOR, D.L. Influência da acurácia de instrumentos de medidas na comparação de métodos de estimativa da evapotranspiração de referência. Irriga, Botucatu, v.13, n.1, p.63-80, 2008.

VESCOVE, H.V.; TURCO, J.E.P. Comparação de três métodos de estimativa da evapotranspiração de referência para a região de Araraquara - SP. Engenharia Agrícola, Jaboticabal, v. 25, n.3, p.713$721,2005$.

VUOLO, J.E. Fundamentos da teoria de erros. 2.ed. São Paulo: Edgard Blucher, 1996. 249 p 